\title{
EPIDEMIC SITUATION OF AVIAN INFLUENZA IN UKRAINE AND IN THE WORLD DURING 2019-2020
}

\author{
Sapachova M. A., Sushko M. I., Mandyhra S. S., Movchun O. M., Skorokhod A. O., \\ Posna O. V., Terletska K. M., Zahrebelnyi V. O., Mezhenskyi A. O. \\ State Scientific and Research Institute of Laboratory Diagnostics and Veterinary \\ and Sanitary Expertise, Kyiv, Ukraine, e-mail: mandygra@ukr.net
}

\begin{abstract}
Summary. The aim of the work was to analyze current epidemic situation on highly pathogenic avian influenza worldwide and in Ukraine during 2019-2020. The research was conducted in the framework of state control of infectious animal diseases. The results of PCR tests obtained in the State Scientific and Research Institute of Laboratory Diagnostics and Veterinary and Sanitary Expertise and in regional state laboratories, data of OIE website (http://www.oie.int) in 2019 and 2020 were analyzed and summarized. During 2019-2020 outbreaks of highly pathogenic avian influenza were detected in 53 countries of the World: in Europe - 22, in Asia - 21, in Africa - 7, in America - 2, and in Australia - 1. In 2019 there was not registered any case of the highly pathogenic avian influenza in Ukraine. In 2020 nine outbreaks of avian influenza were registered in commercial poultry farms $(n=2)$ and backyards $(n=7)$ of Vinnytsia, Mykolaiv, Kyiv, and Kherson regions of Ukraine. It was confirmed that all characterized viruses were closely related and belonged to the highly pathogenic avian influenza virus H5N8 clade 2.3.4.4b identical to the avian influenza viruses currently circulating in Europe and Asia. Wild birds were identified as the main modes of HPAIV spread
\end{abstract}

Keywords: highly pathogenic avian influenza, H5N8, outbreaks

Introduction. Avian influenza (AI) is an infectious and contagious viral disease of birds. The etiological agent is a negative-sense, single-strand RNA virus with a segmented genome that belongs to the Orthomyxoviridae family Influenzavirus A genera. Type A influenza virus can affect wild birds as well as food producing birds (chickens, turkeys, quails, guinea fowls, etc.) and pet birds, some subtypes of virus cause high mortality rates. The virus has also been isolated from mammalian species including humans. Based on the antigenic structure of the surface glycoproteins type A influenza viruses have been classified into 16 hemagglutinin (HA) subtypes and 9 neuraminidase (NA) subtypes that replicates in birds in different combinations (Alexander, 2007; Cox et al., 2000). Recently, two additional HA and NA subtypes (H17N10 and H18N11) subtypes have been detected in bats (Tong et al., 2012, 2013). Theoretically, thousands of different combinations of HA and NA are possible.

Avian influenza viruses (AIVs) commonly detected in the wild birds in most cases are avirulent or cause only mild clinical signs (reduced body weight) (Feare, 2010; The Global Consortium for H5N8 and Related Influenza Viruses, 2016), and are referred to low pathogenic avian influenza virus (LPAIV). However, LPAIV subtypes have the capacity to mutate and become high pathogenic avian influenza virus (HPAIV) - a systemic disorder with an acute clinical course and high mortality rate (Alexander, 2007). It is supposed that the transformation occurs during transmission from wild birds and adaptation of LPAIV to poultry (Feare, 2010; The Global Consortium for H5N8 and Related Influenza Viruses, 2016). From the 16 HA subtypes of AIV detected in wild birds, only $\mathrm{H} 5$ and $\mathrm{H} 7$ subtypes (regardless of the $\mathrm{N}$ subtype) have the potential to mutate. According to the World Organisation for Animal Health (OIE), AIV is defined as an any influenza A virus with high pathogenicity (HPAI) and $\mathrm{H} 5$ and $\mathrm{H} 7$ subtypes with low pathogenicity (H5/H7 LPAI)'. OIE requires notification for all $\mathrm{H} 7$ and $\mathrm{H} 5$ subtypes, regardless of their pathogenicity (OIE).

The economic impact of AIV on poultry is severe, since not only the decreasing of egg production and a high mortality (may reach 100\%) in birds are observed, but also a significant restriction in trade. Another subject of concerning is the ability of AIV to genetic reassortments that can lead to development of advanced human strains (Feare, 2010; Gaidet et al., 2010; King et al., 2020).

AIV s are spread globally thanks to reservoirs such as birds. Due to passage through the territory of Ukraine of a large number of transcontinental migration routes of wild migratory birds (pass from North Asia and Europe to the Mediterranean, Africa, and Southwest Asia and cross from the Baltic and Caspian seas to the Black and Mediterranean seas, and from Western Siberia and Kazakhstan to Western Europe and North Africa), sharing common border with countries where cases of AI were registered and trade relations with these countries, there is a high risk of introduction of AIV into the territory of Ukraine (Muzyka et al., 2012, 2017; Sapachova et al., 2019).

The necessity of epidemiological surveillance on AI determined by the risk of introduction of new virus strains into the country and penetration of the virus into commercial poultry farms and backyards, the emergence of epidemics that can lead to great economic losses.

The aim of the study was to analyze epidemic situation on HPAI in the World and in Ukraine during 2019-2020. 
Materials and methods. The research was conducted in the framework of state control of infectious animal diseases. The results of PCR tests obtained in the State Scientific and Research Institute of Laboratory Diagnostics and Veterinary and Sanitary Expertise and in regional state laboratories in 2019 and 2020 were analyzed and summarized. Data of OIE website (http://www.oie.int) and materials of scientific publications were used.

Samples. During 2019-2020, 7,934 samples of internal organs (intestines, lungs, heart, and trachea), cloacal and tracheal swabs from poultry were tested. In addition, 5,659 wild birds (mainly comprising duck, swans, and pigeons) were examined in the same period. A standard set of organ samples, oropharyngeal and cloacal swabs, poultry manure were collected from dead or shot wild birds.

Virus detection and subtyping. Cloacal and tracheal swabs were immersed in $1 \mathrm{ml}$ of phosphate buffered saline (PBS), shaken and centrifuged for $10 \mathrm{~min}$ at $3,000 \mathrm{~g}$. From organ samples $10 \%$ suspensions were prepared, centrifuged for $10 \mathrm{~min}$ at $3,000 \mathrm{~g}$. Total RNA was extracted from $0.2 \mathrm{~mL}$ of supernatant using a IndiSpin Pathogen Kit (Indical Bioscience, Germany) and reagents for column isolation of RNA/DNA 'ArtRNA MiniSpin' (ArtBioTech, Belarus) according to the manufacturer's protocol. The detection of AIV RNA (detection of the Mgene) was performed using a VetMAX ${ }^{\mathrm{m}}$-Gold AIV Detection Kit (Avian Influenza Virus RNA Test Kit) (Thermo Fisher Scientific). In the case of positive samples, the subtyping hemagglutinins $\mathrm{H} 5$ and $\mathrm{H} 7$ were carried out by Adiavet AIV H5-H7 Real Time (Adiagène SARL, France). RT-PCR for the N8 gene were carried out using AgPath-ID ${ }^{\mathrm{mm}}$ One-Step RT-PCR Reagents (Ambion-Applied Biosystems) with N8 RTPCR primers and probe, described by Hoffmann et al. (2016).

Virus sequencing. The pathogenicity of AIV were determine according to a SOP 'One Step PCR for detection of $\mathrm{H} 5$ and $\mathrm{H} 7$ avian influenza virus and cleavage site sequencing' used by the OIE/FAO international reference laboratory for AI at the Animal and Plant Health Agency (Weybridge, UK).

Samples containing AI virus type A subtype H5N8 were submitted to OIE reference laboratory (Animal and Plant Health Agency, Weybridge, UK) for AIV pathogenicity determination and full genome sequencing. The RNA nucleotide sequences were compared to nucleotide sequences of RNA viruses circulated in Europe and Asia, nucleotide sequences of RNA viruses were obtained from NCBI and GISAID EpiFlu databases. Sequence comparisons were performed with the BLAST.

Results and discussion. During 2019-2020 outbreaks of highly pathogenic avian influenza were registered in 53 countries of the World: in Europe - 22, Asia - 21, Africa - 7, America - 2, and in Australia - 1 (Table 1).

According to data shown in Table 1, the most diversity of various $\mathrm{H} 5$ subtypes of HPAIV circulate in
Asia (H5N1, H5N2, H5N5, H5N6, and H5N8). In Africa H5N1, H5N2, H5N6, and H5N8 were detected. In most European countries circulating of H5N8 of HPAIV were observed, H5N6 was detected only in Denmark and Ireland, H5N1 in Italy, United Kingdom, and the Netherlands. H7 subtypes of HPAIV were detected in America (H7N3 in Mexico, USA) and Oceania (H7N7 in Australia).

Table 1 - Circulation of HPAIV (types H5 and H7) in the World in 2019-2020

\begin{tabular}{|c|c|}
\hline AIV type & Country \\
\hline$\overline{\mathrm{H} 5}$ & \\
\hline H5N1 & $\begin{array}{l}\text { Bhutan, China, India, Laos, Nepal, Nigeria, } \\
\text { Togo, Vietnam, Italy, United Kingdom, } \\
\text { The Netherlands }\end{array}$ \\
\hline H5N2 & Chinese Taipei, Egypt \\
\hline H5N5 & $\begin{array}{l}\text { Belgium, Chinese Taipei, Denmark, } \\
\text { Germany, United Kingdom, Sweden, } \\
\text { Taiwan, The Netherlands }\end{array}$ \\
\hline H5N6 & $\begin{array}{l}\text { Cambodia, China, Denmark, Ireland, } \\
\text { Nigeria, Philippines, Vietnam }\end{array}$ \\
\hline H5N8 & $\begin{array}{l}\text { Belgium, Bulgaria, Czech Republic, Congo, } \\
\text { Denmark, Croatia, France, Germany, } \\
\text { Hungary, Iran, Iraq, Italy, Ireland, Israel, } \\
\text { Japan, Kazakhstan, Kuwait, Korea, Namibia, } \\
\text { Nigeria, Norway, Pakistan, Poland, Romania, } \\
\text { Russia, Ukraine, United Kingdom, Saudi } \\
\text { Arabia, Slovakia, Slovenia, South Africa, } \\
\text { South Korea, Sweden, Spain, The Netherlands }\end{array}$ \\
\hline H7 & \\
\hline H7N3 & Mexico, United States of America \\
\hline H7N7 & Australia \\
\hline
\end{tabular}

The analysis of an epidemiological situation of AI in Ukraine during 2019-2020 was carried out (Tables 2-3). In 2019-2020, 13,593 samples of pathological material and swabs were tested by RT-qPCR, which includes 5,659 samples from wild birds and 7,934 - from domestic. Samples of internal organs (intestines, lungs, heart and trachea), cloacal and tracheal swabs, as well as poultry manure were taken for the testing.

Table 2 - The results of AIV type A detection in pathological material from birds

\begin{tabular}{|c|c|c|c|c|c|c|}
\hline \multirow{3}{*}{ Year } & \multicolumn{5}{|c|}{ Object of study } \\
\cline { 2 - 7 } & \multicolumn{3}{|c|}{ Poultry } & \multicolumn{3}{c|}{ Wild birds } \\
\cline { 2 - 7 } & $\begin{array}{c}\text { Tested } \\
\text { samples }\end{array}$ & Positive & $\%$ & $\begin{array}{c}\text { Tested } \\
\text { samples }\end{array}$ & Positive & $\%$ \\
\hline 2019 & 111 & 0 & 0 & 2,367 & 0 & 0 \\
\hline 2020 & 7,823 & 149 & 1.90 & 3,292 & 4 & 0.12 \\
\hline Total & 7,934 & 149 & 1.88 & 5,659 & 4 & 0.07 \\
\hline
\end{tabular}

In 2019 positive samples on AIV type A were not detected. In 2020, 153 positive samples on AI type A (149 samples from poultry and $4-$ from wild birds) 
were detected. All AI positive samples were typed on $\mathrm{H} 5$ and $\mathrm{H} 7$ subtypes.

According to the data in Table 3 , presence of AIV subtype H5 were confirmed only in 54 samples of pathological material and in 30 samples of cloacal and tracheal swabs of poultry of Vinnytsia, Kherson, Kyiv and Mykolaiv regions. In sample of pathological material of poultry of Ternopil, Odesa, Kharkiv regions and samples of pathological material of wild bird of Odesa and Kherson regions $\mathrm{H} 5$ and $\mathrm{H} 7$ subtypes of AIV type A were not detected.

In general 9 outbreaks of AI there were registered in Vinnytsia (1), Mykolaiv (5), Kyiv (2) and Kherson (1) regions (Table 4).

Table 3 - The results of AIV type A subtyping on hemagglutinins $\mathrm{H} 5$ and $\mathrm{H} 7$

\begin{tabular}{|c|l|l|c|c|c|}
\hline \multirow{2}{*}{ No } & \multirow{2}{*}{ Region } & \multicolumn{1}{c|}{ Type of sample } & Number of & \multicolumn{2}{c|}{ Hemagglutinin subtype } \\
\cline { 5 - 6 } & & samples & H5 & H7 \\
\hline \multirow{2}{*}{1} & \multirow{2}{*}{ Vinnytsia } & pathological material of poultry & 36 & 25 & 0 \\
\cline { 3 - 6 } & & swabs (cloaca and trachea) of poultry & 30 & 30 & 0 \\
\hline 2 & Ternopil & pathological material of poultry & 1 & 0 & 0 \\
\hline \multirow{2}{*}{3} & \multirow{2}{*}{ Odesa } & pathological material of wild birds & 2 & & \\
\cline { 3 - 6 } & & pathological material of poultry & 19 & 0 & 0 \\
\hline \multirow{2}{*}{4} & \multirow{2}{*}{ Kherson } & pathological material of wild birds & 2 & 0 & 0 \\
\cline { 3 - 6 } & & pathological material of poultry & 5 & 5 & 0 \\
\hline \multirow{2}{*}{5} & \multirow{2}{*}{ Kyiv } & pathological material of poultry & 6 & 6 & 0 \\
\cline { 3 - 6 } & & poultry manure & 1 & 0 & 0 \\
\hline 6 & Mykolaiv & pathological material of poultry & 35 & 16 & 0 \\
\hline 7 & Kharkiv & pathological material of poultry & 153 & 0 & 0 \\
\hline
\end{tabular}

Table 4 - Outbreaks of AI in Ukraine in 2020

\begin{tabular}{|c|l|c|c|c|c|c|c|c|}
\hline Date & Outbreak location & Susceptible & Cases & Deaths & Killed & $\begin{array}{c}\text { Morbidity } \\
\text { rate, \% }\end{array}$ & $\begin{array}{c}\text { Mortality } \\
\text { rate,\% }\end{array}$ & $\begin{array}{c}\text { Fatality } \\
\text { rate,\% }\end{array}$ \\
\hline 18.01 .2020 & $\begin{array}{l}\text { Buhakiv, Nemyriv District, } \\
\text { Vinnytsia Region (farm) }\end{array}$ & 116,544 & 7,856 & 7,856 & 108,688 & 6.74 & 6.74 & 100 \\
\hline 02.12 .2020 & $\begin{array}{l}\text { Kandybyne, Nova Odesa District, } \\
\text { Mykolaiv Region (backyard) }\end{array}$ & 10 & 10 & 10 & 0 & 100 & 100 & 100 \\
\hline 08.12.2020 & $\begin{array}{l}\text { Novomatviivske, Nova Odesa } \\
\text { District, Mykolaiv Region (village) }\end{array}$ & 115 & 3 & 0 & 20 & 2.61 & 0 & 0 \\
\hline 23.12 .2020 & $\begin{array}{l}\text { Yaselka, Ochakiv District, } \\
\text { Mykolaiv Region (backyard) }\end{array}$ & 21 & 3 & 3 & 18 & 14.29 & 14.29 & 100 \\
\hline 23.12 .2020 & $\begin{array}{l}\text { Leonivka, Ivankiv District, } \\
\text { Kyiv Region (village) }\end{array}$ & 463 & 463 & 463 & 0 & 100 & 100 & 100 \\
\hline 26.12 .2020 & $\begin{array}{l}\text { Borodianka, Borodianka District, } \\
\text { Kyiv Region (backyard) }\end{array}$ & 1 & 1 & 1 & 0 & 100 & 100 & 100 \\
\hline 28.12 .2020 & $\begin{array}{l}\text { Trykhaty, Mykolaiv District, } \\
\text { Mykolaiv Region (backyard) }\end{array}$ & 16 & 1 & 1 & 15 & 6,25 & 6.25 & 100 \\
\hline 28.12 .2020 & $\begin{array}{l}\text { Ivanivka, Arbuzynka District, } \\
\text { Mykolaiv Region (farm) }\end{array}$ & 98,264 & 587 & 587 & 15 & 0.60 & 0.60 & 100 \\
\hline 28.12 .2020 & $\begin{array}{l}\text { Zaozerne, Kakhovka District, } \\
\text { Kherson Region (backyard) }\end{array}$ & 43 & 26 & 26 & 17 & 60.47 & 60.47 & 100 \\
\hline
\end{tabular}

The first outbreak of AI was registered in an industrial poultry farm with a total number of layers over 98,000 in Vinnytsia Region (Buhakiv Village of Nemyriv District) on 18 January 2020. The outbreak was detected in the course of passive surveillance at an establishment for laying hens. It was the first outbreak of AI caused by HPAI H5N8 virus in our country over the last 3 years. The presence of HPAIV type A subtype $\mathrm{H} 5 \mathrm{~N} 8$ in the poultry samples were confirmed by OIE reference laboratory in Animal and Plant Health Agency (Weybridge, UK). Whole genome sequence analysis was shown high identity with European $\mathrm{H} 5 \mathrm{~N} 8$ viruses (i.e. Poland and Slovakia 2020) clade 2.3.4.4b. The genotype of the virus is the same as those viruses that have been detected in domestic and wild birds in Europe since December 2019. They are reassortants of LPAI viruses from Eurasia and HPAI A (H5N8) viruses from Africa. In particular, $\mathrm{PB} 1$ and NP genes derive from Eurasian 
wild bird strains and the remaining genes are most similar to viruses circulated in West Africa in 2019. It is likely that this reassortment occurred in wild migratory birds in Asia during the summer and then spread to Eastern Europe with the autumn migration of birds.

The first outbreak was quickly eradicated. Correct and quick reaction on this first outbreak that was slaughtering of all susceptible poultries in the farm (108,688 birds) and undertaken veterinary and sanitary measures helped to stop spreading of the AIV.

Another eight outbreaks of HPAIV were registered during December 2020.

AI outbreaks were registered in five districts of the Mykolaiv region: two outbreaks in backyards in Nova Odesa District (in Kandybyne Village 02.12.2020 and in Novomatviivske Village 08.12.2020); single outbreaks in backyards in Ochakiv (Yaselka Village 23.12.2020) and Mykolaiv districts (Trykhaty Village, 28.12.2020); and on an industrial poultry farm in Arbuzynka Ditrict (Ivanivka Village 28.12.2020).

In Kyiv Region two AI outbreaks were registered. First outbreak of AIV type A subtype H5N8 were registered 23.12.2020 in poultry (23 turkeys and 440 chickens) founded on a roadside in a distance $1 \mathrm{~km}$ from Leonivka Village Ivankiv District. Second outbreak of AI was recorded 26.12.2020 in a backyard in Borodianka Village Borodianka District during an epidemiological investigation of the AI outbreak in Ivankiv District.

28.12.2020 AI outbreak was registered in poultry in a backyard in Zaozerne Village Kakhovka District Kherson Region.

The source of infection has not been found yet for any of the registered outbreaks of AI. Wild birds are the most likely source of AIV in our country, even considering the fact that in farms the poultry did not have outdoor access. Indirect contact with infected wild birds thought polluted environment by infected birds can lead to AIV spreading. Analysis of migration routes of wild birds indicates that Mykolaiv, Odessa, and Kherson regions are located at the crossing of wild bird migratory routes, so the risk of introduction of AIV by wild migratory birds is high.

The higher number of outbreaks observed in poultry and it absence in wild birds could be explained by an ineffective passive surveillance of wild birds, by a different host response to virus infection between domestic and wild birds, or by herd immunity of wild birds due to past seasons' exposure to HPAI A (H5).

Conclusions. During 2020, nine outbreaks of AI were detected in two commercial poultry farms and in seven backyards of Vinnytsia (1), Mykolaiv (5), Kyiv (2), and Kherson (1) regions in Ukraine. It was confirmed that all isolated viruses were closely related and belonged to the HPAIV H5N8 clade 2.3.4.4b identical to the AIV that are currently circulating in Europe and Asia. Wild birds and human activity were identified as the main modes of HPAIV spread. Further epidemiological studies should be directed to identifying possible risk factors and understanding routes of AIV spreading. Systematic surveillance and prevention epidemiological measures need to be continuing.

Acknowledgement. The authors are grateful to colleagues from Animal and Plant Health Agency (Weybridge, UK) for the help on AI pathogenicity confirmation and full genome sequencing of influenza $\mathrm{A}$ virus isolates (H5N8) which were collected during the outbreaks in Ukraine.

\section{References}

Alexander, D. J. (2007) 'An overview of the epidemiology of avian influenza', Vaccine, 25(30), pp.5637-5644. doi: 10.1016/j.vaccine.2006.10.051.

Cox, N. J., Fuller, F., Kaverin, N., Klenk, H. D., Lamb, R. A., Mahy, B. W., McCauley, J., Nakamura, K., Palese, P., Webster, R. (2000) 'Orthomyxoviridae', in Van Regenmortel, C. M. F. M. H. V., Bishop, D. H. L., Carstens, E. B., Estes, M. K., Lemon, S. M., Maniloff, J., Mayo, M. A., McGeoch, D. J., Pringle, C. R. and Wickner, R. B. (eds.) (2000) Virus taxonomy: Seventh Report of the International Committee on Taxonomy of Viruses. San Diego, CA: Academic Press, pp. 585-597. ISBN 9780127141817.

Feare, C. J. (2010) 'Role of wild birds in the spread of highly pathogenic avian influenza virus $\mathrm{H} 5 \mathrm{~N} 1$ and implications for global surveillance', Avian Diseases, 54(s1), pp. 201-212. doi: 10.1637/8766-033109-ResNote.1.

Gaidet, N., Cappelle, J., Takekawa, J. Y., Prosser, D. J., Iverson, S. A., Douglas, D. C., Perry, W. M., Mundkur, T. and Newman, S. H. (2010) 'Potential spread of highly pathogenic avian influenza $\mathrm{H} 5 \mathrm{~N} 1$ by wildfowl: dispersal ranges and rates determined from large-scale satellite telemetry: Potential dispersal of H5N1 HPAI virus by wildfowl', Journal of Applied Ecology, 47(5), pp. 1147-1157. doi: 10.1111/j.1365-2664.2010. 01845.x.
Hoffmann, B., Hoffmann, D., Henritzi, D., Beer, M. and Harder, T. C. (2016) 'Riems influenza a typing array (RITA): An RT-qPCR-based low density array for subtyping avian and mammalian influenza A viruses', Scientific Reports, 6(1), p. 27211. doi: 10.1038/srep27211.

King, J., Schulze, C., Engelhardt, A., Hlinak, A., Lennermann, S.-L., $\quad$ Rigbers, K., Skuballa, J., Staubach, C., Mettenleiter, T. C., Harder, T., Beer, M. and Pohlmann, A. (2020) 'Novel HPAIV H5N8 reassortant (clade 2.3.4.4b) detected in Germany', Viruses, 12(3), p. 281. doi: 10.3390/ v12030281.

Muzyka, D., $\quad$ Pantin-Jackwood, M., Spackman, E., Stegniy, B., Rula, O. and Shutchenko, P. (2012) 'Avian influenza virus wild bird surveillance in the Azov and Black Sea regions of Ukraine (2010-2011)', Avian Diseases, 56(4s1), pp. 1010-1016. doi: 10.1637/10157-040912-ResNote.1.

Muzyka, D. V., Nevolko, O. M., Gerilovych, A. P., Stegniy, A. B., Novozhytska, Yu. M., Rula, O. M., Tkachenko, S. V. (2017) 'Highly pathogenic avian influenza in the World and Ukraine' [Vysokopatohennyi hryp ptytsi u sviti ta Ukraini], Veterinary medicine [Veterynarna medytsyna], 103, pp. 198-201. Available at: https://elibrary.ru/item.asp?id=29799761. [in Ukrainian]. 
Sapachova, M., Pishchanskyi, O., Sushko, M., Usachenko, N. and Mezhenskyi, A. (2019) 'Results of laboratory control of some infectious animal diseases in Ukraine in 2018 using molecular-genetic methods' [Rezultaty laboratornoho kontroliu deiakykh infektsiinykh khvorob tvaryn v Ukraini u 2018 rotsi molekuliarno-henetychnymy metodamy], Veterinary biotechnology [Veterynarna biotekhnolohiia], 34, pp. 136-140. doi: 10.31073/vet_biotech34-16.

The Global Consortium for H5N8 and Related Influenza Viruses (2016) 'Role for migratory wild birds in the global spread of avian influenza H5N8', Science, 354(6309), pp. 213217. doi: $10.1126 /$ science.aaf8852.

Tong, S., Li, Y., Rivailler, P., Conrardy, C., Castillo, D. A. A., Chen, L.-M., Recuenco, S., Ellison, J. A., Davis, C. T., York, I. A.,
Turmelle, A. S., Moran, D., Rogers, S., Shi, M., Tao, Y., Weil, M. R. Tang, K., Rowe, L. A., Sammons, S., Xu, X., Frace, M., Lindblade, K. A., Cox, N. J., Anderson, L. J., Rupprecht, C. E. and Donis, R. O. (2012) 'A distinct lineage of influenza A virus from bats', Proceedings of the National Academy of Sciences, 109(11), pp. 4269-4274. doi: 10.1073/pnas.1116200109.

Tong, S., Zhu, X., Li, Y., Shi, M., Zhang, J., Bourgeois, M., Yang, H., Chen, X., Recuenco, S., Gomez, J., Chen, L.-M., Johnson, A., $\quad$ Tao, Y., $\quad$ Dreyfus, C., $\quad$ Yu, W., McBride, R., Carney, P. J., Gilbert, A. T., Chang, J., Guo, Z., Davis, C. T., Paulson, J. C., Stevens, J., $\quad$ Rupprecht, C. E., Holmes, E. C., Wilson, I. A. and Donis, R. O. (2013) 'New World bats harbor diverse influenza A viruses', PLoS Pathogens, 9(10), p. e1003657. doi: 10.1371/journal.ppat.1003657. 